\title{
Vaccination Coverage among Health Care Workers in A Greek Hospital
}

\author{
Saridi $\mathbf{M}^{1}$, Toska $\mathrm{A}^{1}$, Souliotis $\mathrm{K}^{2}$, Orfanos $\mathbf{N}^{3}$ Sietou $\mathbf{M}^{3}$, Stamatiou $\mathrm{K}^{4 *}$ and Farmaki $\mathrm{K}^{1}$
}

${ }^{1}$ Transfusion Unit, General Hospital of Korinthos, Greece

2University of Peloponnesse, Greece

${ }^{3}$ Transfusion Unit, General Hospital of Sparta, Greece

${ }^{4}$ Urology Department, General Hospital of Pireas, Greece

\begin{abstract}
Background: According to the $\mathrm{CDC}$ and the Greek Disease Control and Prevention Center recommendations, every Health Professional should be vaccinated against Hepatitis B and Tetanus. A regular screening for Tuberculosis may be held by the hospital infection control unit.
\end{abstract}

Aim: The aim of this study was to investigate health care professionals' compliance to vaccination coverage in order to organize a vaccination schedule.

Method: Our sample consists of 338 professionals working in the General Hospital of Korinthos. The study duration was 2 years. A vaccination schedule has been activated against Hepatitis B and Tetanus, and in some cases a pre-existing schedule was carried on, according to each professional's personal vaccination history.

Results: $59.8 \%$ of the sample was nurses, $19.5 \%$ were physicians, $7.4 \%$ were members of the Technical Services, $6.5 \%$ were members of the Cleaning Staff, and 3.8\% were members of the Administrative Services. 58.6\% of the sample were vaccinated against Hepatitis B, while only $15.4 \%$ were vaccinated against Tetanus. Anti-HBs positive were $47.6 \%$. Only a small percentage of them were HBsAg-positive (1.2\%), $6.5 \%$ of them were also AntiHBc-positive, and only $0.3 \%$ was Anti-HCV-positive. A Mantoux Tuberculin Skin Test was performed on $27.5 \%$ of the sample and $28 \%$ of them were found positive; after a thorough clinical examination, no TB infection was detected.

Conclusions: The investigation of health care professionals' compliance to vaccination coverage contributed to the success of the vaccination schedule.

Keywords: Immunization, Health care workers, Vaccination, Immunization status

\section{Background}

Due to contact with patients and/or blood and other specimens, health professionals risk exposure and possible transmission of several diseases that can be prevented via vaccination. Hence, maintaining a high immunization level makes up an important part of disease prevention and control programs targeted on health professionals. Any health care institutions providing direct care to patients should be encouraged to apply a compact immunization policy for each and every professional working there. The American Hospital Association has fully acknowledged the need for immunization protocols both for health professionals and patients. During the development of such protocols, the ACIP (Advisory Committee on Immunization Practices) recommendations should be taken under serious consideration [1] The CDC recommends that health professionals should be vaccinated against Hepatitis B, Influenza, Parotitis, Measles, Rubella, Varicella, Tetanus, and Diphtheria [2].

\section{Aim}

The main objective of this study is to investigate the vaccination coverage levels of the professionals working in the General Hospital of Korinthos, Greece. A professional exposure to blood and body fluids registry was also brought into action. The ulterior purpose of this study was to inform our colleagues about the national vaccination program, recommended by the local [Greek] Disease Control and Prevention Center.

\section{Method}

Participants in this study accepted a prior pre-test interview with the investigators at their working place (eg. outpatient department, office, clinic, etc) after which they received additional written information and the study's questionnaires. These were printed forms gathering information about the age, educational and professional data of the participants as well as the immunization level for Hepatitis B, Hepatitis C, Tetanus and Tuberculosis. Information on accidental exposure to body fluids was also asked. The content of discussion was strictly determined, while subjects had enough time for questions and answers.

\section{Study population}

Our study took place from June 2006 to June 2008. The Hospital staff took part in the study. The total number of the Hospital staff amounts to 380 people, including all job categories (medical, nursing, administrative, laboratory and technical personnel). In addition, two more categories were included, private assistant nurses, and cleaning staff (40 persons in total). The total sample was consisted of 420 professionals. Sixty-eight out of these 420 professionals were excluded from the study ( 32 out of these 68 persons were absent at the enrolment and 36 did not give their consent).

${ }^{*}$ Corresponding author: Dr. Konstantinos Stamatiou , Urology Department General Hospital of Pireas, 2 Salepoula street.18536, Pireas, Greece, E-mail: stamatiouk@gmail.com

Received September 15, 2011; Accepted October 20, 2011; Published Octobe 27, 2011

Citation: Saridi M, Toska A, Souliotis K, Orfanos N Sietou M, et al. (2011) Vaccination Coverage among Health Care Workers in A Greek Hospital. J Vaccines Vaccin 2:123. doi:10.4172/2157-7560.1000123

Copyright: $\odot 2011$ Saridi M, et al. This is an open-access article distributed unde the terms of the Creative Commons Attribution License, which permits unrestricted use, distribution, and reproduction in any medium, provided the original author and source are credited. 
The Hepatitis B and the Diphtheria-Tetanus vaccines were also included in the vaccination program. Immunology testing included Hepatitis B, C, and Tuberculosis.

\section{Data collection}

Before the initiation of the program, all the hospital professionals were informed and a detailed schedule was formed including all the staff of every department. Mantoux skin tests were performed at the Hospital Anti-Tuberculosis Office by the local staff that also filled out the respective forms. The immunological tests were performed at the Hospital Blood Bank by the Infection Control Nurses. Counting the costs and the staff availability, a limit of blood specimens' tests were examined every month.

During the second year of the study (2007-2008), all incidents of professional exposure to blood or body fluids were recorded in order to assess the compliance of the staff to the vaccination program.

Partecipants had continuous personal contacts with the Infection Control Nurses.

\section{Laboratory testing for hepatitis}

It was realized with the automatic immuno-analyzer ARCITECT, i2000SR, ABBOTT, based on a two-step assay using Chemiluminescent microparticule immunoassay (CMIA) technology.

With CMIA technology we measured:

Hepatitis B indices:

- HBsAg: surface antigen of Hepatitis B virus for the two subtypes ad and ay.

- Anti-HBs: antibody to surface antigen

- Anti-HBc: antibody to core antigen

- HB-eAg: e antigen

- Anti-HBe: antibody to e antigen

Hepatitis $\mathrm{C}$ indices:

- Anti-HCV for detection of total antibody to HCV including core, NS3, NS4 \& NS5.

Anti-HBs levels had been checked four weeks after the third immunization

\section{Statistical analysis}

Categorical variables are expressed with absolute and relative frequencies. Chi-square and Fishers's exact tests were used for the comparison of proportions. $\mathrm{P}$ value for trend in rates for title of antibodies $\geq 100$ by the number of doses was also estimated. All reported $p$ values are two-tailed. Statistical significance was set at $p \leq 0.05$ and analyses were conducted using SPSS statistical software (version 13.0).

\section{Ethics}

A research protocol was presented by the Infection Control Unit to the Scientific Board of the Hospital of Korinthos. The Board granted its approval for a two-year long study to be conducted, in order to assess the immunological profile of health care workers. Informed consent was given by all participants, and their right to withdraw their consent at any time was fully and explicitly acknowledged. All forms were filled out under absolute anonymity and confidence concerning both the participants and the professionals who processed the data. Before each participant had signed the consent form, they were informed about the questions and the data they had to disclose. Each participant was assigned a personal code number known only to her/him and the Infection Control Nurse. Only the code number was noted on all blood specimens, and the results were handed to the participants personally and discretely.

\section{Results}

\section{Demographics}

14 out of the 352 professionals who were consisted the final sample were excluded from the study for not having completed the forms provided to them. The final study sample consists of 338 participants (29.9\% males, $70.1 \%$ females), Table 3 presents sample characteristics. The participants in their majority were nurses (59.8\%), followed by physicians (19.5\%), technical personnel (10.4\%), and administrative personnel (3.8\%). As far as hospital departments are concerned, $44.4 \%$ of the participants are employed in one of the surgical departments, $16.6 \%$ in one of the internal medicine departments, $7.4 \%$ in one of the laboratories, $9.8 \%$ in one of the special care units, and $5 \%$ were private assistant nurses.

\section{Job and education data}

The educational and professional data of the participants (as shown in Table 4) were also recorded. More specifically, as far as the education level is concerned, $30.4 \%$ of our participants had $12-14$ years of education (up to high school plus vocational school), 28.4\% had 16 years of education ('higher education' in Greece), $22.5 \%$ were University graduates, and the remaining $18.9 \%$ had $6-9$ years of education (Figure 1, supra). As far as years of employment are concerned, $57.1 \%$ of the participants had over 10 years of employment and $32.8 \%$ of them had 10-20 years of employment.

\section{Immunization level for hepatitis b \& c}

Three doses of the vaccine were administered in order to achieve full protection. The second dose was given one month after the first dose and the third dose was given five months after the second dose. As shown in Table 5, 58.6\% ( $\mathrm{n}=198)$ of the participants $(\mathrm{n}=338)$, were fully vaccinated against Hepatitis B. More specifically, out of 198 vaccinees, 51 of them were physicians, 122 were nurses, 23 worked for the Technical Services, and 2 for the Administrative Services (Table 8).

As far as dosage compliance was concerned, $80.3 \%$ of the participants had had the full series (3 doses), 15.2\% had had two doses, and $4.5 \%$ had had only one dose administered. Antibody testing showed that $52.4 \%$ of all vaccines developed no antibodies, while $47.6 \%$ were positive. $34.6 \%$ were shown to have antibody titers of over 100 $\mathrm{mIU} / \mathrm{mL}$, and -as shown in Figure 2- the more doses administered, the more antibodies detected ( $\mathrm{p}$ for trend $<0.001$ ).

Of those vaccinated against Hepatitis B, 65.4\% developed antibody levels $<100 \mathrm{mIU} / \mathrm{mL}, 33,7 \%$ developed antibody levels between 100 $1000 \mathrm{mIU} / \mathrm{mL}$, and only $0,9 \%$ of them developed antibody levels $>1000$ $\mathrm{mIU} / \mathrm{mL}$.

During the HBV serological markers testing, $1.2 \%(n=4)$ of our participants were tested HBsAg-positive, yet HBeAg was not detected. 22 individuals (6.5\%) were tested positive for anti-HBc (Table 6). All participants were also tested for anti-HCV; only one individual $(0.3 \%)$ was anti-HCV positive. 
Citation: Saridi M, Toska A, Souliotis K, Orfanos N Sietou M, et al. (2011) Vaccination Coverage among Health Care Workers in A Greek Hospital. J Vaccines Vaccin 2:123. doi:10.4172/2157-7560.1000123

Page 3 of 8

\begin{tabular}{|c|c|c|}
\hline Tests & Results & Interpretation \\
\hline $\begin{array}{l}\text { HBsAg } \\
\text { anti-HBc } \\
\text { anti-HBs }\end{array}$ & $\begin{array}{l}\text { negative } \\
\text { negative } \\
\text { negative }\end{array}$ & $\begin{array}{l}\text { Susceptible } \\
\text { Vaccination recommended }\end{array}$ \\
\hline $\begin{array}{l}\text { HBsAg } \\
\text { anti-HBc } \\
\text { anti-HBs }\end{array}$ & $\begin{array}{l}\text { negative } \\
\text { negative } \\
\text { positive }\end{array}$ & Immune due to vaccination \\
\hline $\begin{array}{l}\text { HBsAg } \\
\text { anti-HBc } \\
\text { anti-HBs }\end{array}$ & $\begin{array}{l}\text { negative } \\
\text { positive } \\
\text { positive }\end{array}$ & $\begin{array}{l}\text { Immune due to natural infection } \\
\text { No re-testing or vaccination needed }\end{array}$ \\
\hline $\begin{array}{l}\text { HBsAg } \\
\text { anti-HBc } \\
\text { IgM anti-HBc } \\
\text { anti-HBs }\end{array}$ & $\begin{array}{l}\text { positive } \\
\text { positive } \\
\text { positive } \\
\text { negative }\end{array}$ & $\begin{array}{l}\text { Acutely infected } \\
\text { Increased infectiousness; the patient should consult a hepatologist }\end{array}$ \\
\hline $\begin{array}{l}\text { HBsAg } \\
\text { anti-HBc } \\
\text { IgM anti-HBc } \\
\text { anti-HBs }\end{array}$ & $\begin{array}{l}\text { positive } \\
\text { positive } \\
\text { negative } \\
\text { negative }\end{array}$ & $\begin{array}{l}\text { Chronically infected } \\
\text { - The patient should consult a hepatologist }\end{array}$ \\
\hline $\begin{array}{l}\text { HBsAg } \\
\text { anti-HBc } \\
\text { anti-HBs }\end{array}$ & $\begin{array}{l}\text { negative } \\
\text { positive } \\
\text { negative }\end{array}$ & $\begin{array}{l}\text { Possible interpretations: The person might be: } \\
\text { 1. Recovering from acute HBV infection (Window phase) } \\
\text { The person should be tested for IgM anti-HBc } \\
\text { 2. Immune from previous HBV infection and the test is not able to detect a very low level of anti-HBs, or } \\
\text { 3. Susceptible to infection, false positive anti-HBc } \\
\text { Administer one dose of the Hep B Vaccine; four weeks later, if the anti-HBs levels are } \geq 50 I U / L \text {, it is probably } \\
\text { due to natural immunity, otherwise complete the vaccination schedule } \\
\text { 4. Chronically infected, but with undetectable levels of HBsAg } \\
\text { Patient should be tested for HBV DNA. }\end{array}$ \\
\hline
\end{tabular}

Table 1: Interpretation of the Hepatitis B panel.

\section{Vaccination coverage for tetanus and tuberculosis}

52 participants were vaccinated against Tetanus, 26 being nurses, 19 being Technicians and Handymen, and 7 were physicians. $80.5 \%$ of the participants were unable to answer if they had had a DT booster dose, while all of them (100\%) were unacquainted with the fact that a single booster could boost their immunity levels for almost ten years.

$84.6 \%$ of the participants refused to have a Tetanus dose administered, and only $15.4 \%(n=52)$ granted their consent, according to the data shown in Table 7.

A Mantoux skin test was performed on 93 participants (27.5\%), 26 of them being tested positive (28.0\%), and $72 \%$ being negative.

\section{Vaccination level and demographic traits correlation}

Vaccination percentage against Hepatitis $B$ and Tetanus varied according to job category $(\mathrm{p}<0.001)$, (Table 6). More specifically, physicians $(77.3 \%)$, technical personnel (68\%) and nurses $(60.4 \%)$ had the higher percentages for Hepatitis B vaccination, while the administrative personnel and the cleaners had the lowest vaccination percentages ( $15.4 \%$ and $4.5 \%$ respectively).

As far as Tetanus vaccination is concerned, compliance percentages were higher for technical personnel (64.0\%) and handymen $(20.0 \%)$, and lower for nurses (12.9\%), physicians (10.6\%) and administrative/ office personnel $(7.7 \%)$.

Some differences were also observed according to the educational level $(\mathrm{p}<0.001)$, as shown in Table 8.

Compulsory Education individuals had significantly lower percentages of vaccination coverage (against both Hepatitis B and Tetanus), while Higher Education and University graduates had higher vaccination compliance percentage than Secondary Education Certificate persons.
As far as hospital departments and Hepatitis B vaccination level is concerned, professionals working in Special Care Units had the highest vaccination percentage $(78.8 \%)$, followed by professionals of the Internal Medicine Departments (75.0\%), Surgical Depts. (62.7\%), and Laboratories (56\%). Private assistant nurses and other Depts. presented the lowest compliance percentage $(\mathrm{p}<0.001)$.

Vaccination levels against Tetanus increase in accordance to years of employment (Table 8); professionals with 20 or more years of employment have the highest percentage (18.3\%). Vaccination coverage against Tetanus presents similar percentages regardless of education level, although Higher Education graduates present a slightly higher percentage (21.9\%), as shown in Figure 3. Internal Medicine Departments had higher vaccination levels not only against Hepatitis $\mathrm{B}$, but against Tetanus as well (11.7\%), $(\mathrm{p}=0.005)$.

Professionals working in Special Care Units are not vaccinated against Tetanus as often as they do against Hepatitis B (3.0\% vs. 78.8\%).

A Tuberculosis screening, using the Mantoux Skin Test (Table 6), did not present any statistically significant variance as far as gender was concerned; in accordance to job categories, physicians, nurses and office personnel presented similar results.

Some differences were presented according to hospital departments and Mantoux-tested personnel. Surgical Dept. professionals $(36.0 \%)$ and private asst. nurses $(47.1 \%)$ had the highest participation percentage; professionals working in Special Care Units (12.1\%), Laboratories (16\%), and Internal Medicine Depts. (16.1\%) presented low participation levels (Figure 3).

We found noteworthy the fact that the percentage of Mantouxtested professionals is conversely proportional to their level of education, i.e. the higher the educational level, the lower the percentage of professionals tested. On the other hand, as the years of employment increased, the participation also increased. 
Citation: Saridi M, Toska A, Souliotis K, Orfanos N Sietou M, et al. (2011) Vaccination Coverage among Health Care Workers in A Greek Hospital. J Vaccines Vaccin 2:123. doi:10.4172/2157-7560.1000123

Page 4 of 8

\begin{tabular}{|c|c|}
\hline Positive & Induration diameter $\geq 10 \mathrm{~mm}$ \\
\hline Questionable & Induration diameter $5-9 \mathrm{~mm}$ \\
\hline Negative & Induration diameter $<5 \mathrm{~mm}$ \\
\hline A false negative result may be caused by:
\end{tabular}

Table 2: Classification of tuberculin reaction.

\begin{tabular}{|l|l|l|}
\hline & N & $\%$ \\
\hline Males & 101 & 29.9 \\
\hline Females & 237 & 70.1 \\
\hline Job Category & & \\
\hline Physician & 66 & 19.5 \\
\hline Nurse & 202 & 59.8 \\
\hline Administrative & 13 & 3.8 \\
\hline Handyman & 10 & 3.0 \\
\hline Technical & 25 & 7.4 \\
\hline Cleaner & 22 & 6.5 \\
\hline Hospital Department & & \\
\hline Internal Medicine & 56 & 16.6 \\
\hline Surgical & 150 & 44.4 \\
\hline Laboratory & 25 & 7.4 \\
\hline Special Care Units & 33 & 9.8 \\
\hline Other & 57 & 16.9 \\
\hline Private Asst. Nurse & 17 & 5.0 \\
\hline
\end{tabular}

Table 3: Demographics.

\begin{tabular}{|l|l|l|}
\hline & N & $\%$ \\
\hline Educational Level & & \\
\hline Primary Education & 64 & 18.9 \\
\hline Secondary (plus Vocational) Education & 102 & 30.2 \\
\hline Higher Education & 96 & 28.4 \\
\hline University Education & 76 & 22.5 \\
\hline Years of employment & & \\
\hline $1-5$ & 94 & 27.8 \\
\hline $5-10$ & 51 & 15.1 \\
\hline $10-20$ & 111 & 32.8 \\
\hline$>20$ & 82 & 24.3 \\
\hline
\end{tabular}

Table 4: Job data.

\section{Accidental exposure to body fluids}

22 persons in total (6.5\%) reported an accident during the last year of the study. $46 \%(n=10)$ were nurses, $36 \%(n=8)$ were physicians, and $18 \%(n=4)$ were members of the Cleaning Staff.

14 health care workers $(63.6 \%)$ reported needlestick injury, and 8 people (36.4\%) were injured by other sharps. In all (100\%) occasions, blood samples were collected, while in 19 occasions (86.4\%) blood samples were collected off the patient as well (Table 9).

15 persons (68.2\%) were administered a dose of Tetanus Immunoglobulin; the same number ( 15 persons) were also administered a dose of Hepatitis B Immunoglobulin.

$63,6 \%$ of the persons injured, were vaccinated against Hepatitis
B (Table 7). 13.6\% were covered against Tetanus, and $40.9 \%$ had previously received a Mantoux test.

Follow-up testing of injured professionals $(n=18)$ revealed no sign of HBV/HCV infection; four persons $(n=4)$ remained untested, because they were no longer working for the Hospital.

\section{Discussion}

Introduction of vaccination programs for HCWs internationally has resulted in significant reduction of $\mathrm{HBV}$ infections due to accidental exposure to body fluids. Less than 60 cases were reported in 2006 [3]. The Hepatitis B vaccination is the most widely administered vaccination on HCWs not only in Greece, but in other countries as well [4].

As far as our study is concerned, $58.6 \%$ of our participants were vaccinated against Hepatitis $\mathrm{B}, 77.3 \%$ of them being physicians, $68 \%$ technicians, $60.4 \%$ nurses, and $15.4 \%$ hospital cleaners. It should be noted that the high immunization percentage of the technical staff, could be attributed to new training programs targeting on non-medical

\begin{tabular}{|l|l|l|}
\hline & N & $\%$ \\
\hline Hepatitis B Vaccination & & \\
\hline No & 140 & 41.4 \\
\hline Yes & 198 & 58.6 \\
\hline Number of Doses & & \\
\hline 1 & 9 & 4.5 \\
\hline 2 & 30 & 15.2 \\
\hline 3 & 159 & 80.3 \\
\hline Result & & \\
\hline Negative & 177 & 52.4 \\
\hline Positive & 161 & 47.6 \\
\hline Antibody Titer & & \\
\hline$<100 \mathrm{mlU} / \mathrm{mL}$ & 221 & 65.4 \\
\hline $100-1000 \mathrm{mlU} / \mathrm{mL}$ & 114 & 33.7 \\
\hline$>1000 \mathrm{mlU} / \mathrm{mL}$ & 3 & 0.9 \\
\hline & & \\
\hline
\end{tabular}

Table 5: Vaccination Level.

\begin{tabular}{|l|l|l|}
\hline & N & $\%$ \\
\hline HBsAg & & \\
\hline Negative & 334 & 98.8 \\
\hline Positive & 4 & 1.2 \\
\hline Anti-HBc & & \\
\hline Negative & 316 & 93.5 \\
\hline Positive & 22 & 6.5 \\
\hline Anti-HCV & & \\
\hline Negative & 337 & 99.7 \\
\hline Positive & 1 & 0.3 \\
\hline
\end{tabular}

Table 6: HBV \& HBC Serological Markers.

\begin{tabular}{|l|l|l|}
\hline & N & $\%$ \\
\hline Tetanus Vaccination & & \\
\hline No & 286 & 84.6 \\
\hline Yes & 52 & 15.4 \\
\hline Mantoux skin test -performed & & \\
\hline No & 245 & 72.5 \\
\hline Yes & 93 & 27.5 \\
\hline Mantoux skin test --results & & \\
\hline Negative & 67 & 72.0 \\
\hline Positive & 26 & 28.0 \\
\hline
\end{tabular}

Table 7: Tetanus and Tuberculosis Screening. 
Citation: Saridi M, Toska A, Souliotis K, Orfanos N Sietou M, et al. (2011) Vaccination Coverage among Health Care Workers in A Greek Hospital. J Vaccines Vaccin 2:123. doi:10.4172/2157-7560.1000123

Page 5 of 8

\begin{tabular}{|c|c|c|c|c|c|c|c|c|c|}
\hline & \multicolumn{2}{|c|}{ Vaccine hepat. B } & \multirow[b]{2}{*}{$P X^{2}$ test } & \multicolumn{2}{|c|}{ Vaccine tetanus } & \multirow[b]{2}{*}{$P X^{2}$ test } & \multicolumn{2}{|c|}{ TEST Mx } & \multirow[b]{2}{*}{$\mathrm{P} \mathrm{X}^{2}$ test } \\
\hline & $\mathrm{N}$ & $\%$ & & $N$ & $\%$ & & $N$ & $\%$ & \\
\hline \multicolumn{10}{|l|}{ Sex } \\
\hline male & 57 & 56.4 & 0.601 & 21 & 20.8 & 0.072 & 26 & 25.7 & 0.634 \\
\hline female & 141 & 59.5 & & 31 & 13.1 & & 67 & 28.3 & \\
\hline \multicolumn{10}{|l|}{ Job category } \\
\hline Doctor & 51 & 77.3 & $<0.001$ & 7 & 10.6 & $<0.001^{*}$ & 19 & 28.8 & 0.990 \\
\hline Nurse & 122 & 60.4 & & 26 & 12.9 & & 56 & 27.7 & \\
\hline Administrative & 2 & 15.4 & & 1 & 7.7 & & 4 & 30.8 & \\
\hline Handyman & 5 & 50.0 & & 2 & 20.0 & & 3 & 30.0 & \\
\hline Technician & 17 & 68.0 & & 16 & 64.0 & & 6 & 24.0 & \\
\hline Cleaner & 1 & 4.5 & & 0 & 0.0 & & 5 & 22.7 & \\
\hline \multicolumn{10}{|l|}{ Hospital Department } \\
\hline Internal Medicine & 42 & 75.0 & $<0.001$ & 12 & 21.4 & 0.005 & 9 & 16.1 & 0.003 \\
\hline Surgical & 94 & 62.7 & & 21 & 14.0 & & 54 & 36.0 & \\
\hline Laboratory & 14 & 56.0 & & 2 & 8.0 & & 4 & 16.0 & \\
\hline Special Care Units & 26 & 78.8 & & 1 & 3.0 & & 4 & 12.1 & \\
\hline Other & 20 & 35.1 & & 16 & 28.1 & & 14 & 24.6 & \\
\hline Private Asst. Nurse & 2 & 11.8 & & 0 & 0.0 & & 8 & 47.1 & \\
\hline \multicolumn{10}{|l|}{ Educational Level } \\
\hline Primary Education & 13 & 20.3 & $<0.001$ & 7 & 10.9 & 0.141 & 23 & 35.9 & 0.373 \\
\hline Secondary Education & 60 & 58.8 & & 16 & 15.7 & & 28 & 27.5 & \\
\hline Higher Education & 67 & 69.8 & & 21 & 21.9 & & 23 & 24.0 & \\
\hline University Education & 58 & 76.3 & & 8 & 10.5 & & 19 & 25.0 & \\
\hline \multicolumn{10}{|l|}{ Years of employment } \\
\hline $1-5$ & 53 & 56.4 & 0.620 & 11 & 11.7 & 0.455 & 22 & 23.4 & 0.206 \\
\hline 5-10 & 27 & 52.9 & & 6 & 11.8 & & 13 & 25.5 & \\
\hline $10-20$ & 70 & 63.1 & & 20 & 18.0 & & 28 & 25.2 & \\
\hline$>20$ & 48 & 58.5 & & 15 & 18.3 & & 30 & 36.6 & \\
\hline
\end{tabular}

Table 8: Vaccination Coverage in Correlation to Demographic and Job Traits.

staff, and also to a more 'aggressive' information policy implemented by the hospital's Infection Control Unit. In several studies, vaccination coverage percentages range from $71 \%$ to $81 \%$ [5-10], while in some other studies much lower percentages were reported (40\%-53\%) [11-14]. In a similar questionnaire study held in Greece by six hospitals, vaccination coverage for nurses was found to be a little lower (52.2\%)[15]; in another study on student nurses a higher percentage was reported (67\%), which makes us optimistic about new Health Care Workers and their immunization status [16]. Our study, on the other hand, yielded intermediate percentages of immunization against Hepatitis B. $80.3 \%$ of all vaccinees were administered the full 3-dose series, which could be attributed not only to our Infection Control Nurses' alertness, but to our HCWs' continuous briefing on immunization and vaccines.

According to the international literature, the Hepatitis B vaccine is one of the safest and effective vaccines ever developed. Although millions of doses of the vaccine have been administered, rarely have any serious side-effects occurred. Nevertheless, some very rare sideeffects, including Guillain-Barré syndrome [8,17], encephalitis [10], seizures, autoimmune diseases and other side-effects from the CNS, have been attributed to the vaccine.

As far as the present study is concerned, none of our vaccinees reported any adverse reactions, in contrast with an earlier Greek study [15] and also with the study of Mc Ewen et al, where a $10 \%$ of all vaccinated persons reported an adverse reaction, and most commonly a local reaction [10].

Another finding that should also be investigated is the fact that $52.4 \%$ of those vaccinated developed no antibodies; this result is much higher compared to many other studies' $[12,18]$ findings (10\%-12\% developed no antibodies or low antibody titers).
Our study also suggests a correlation between vaccination status and demographic data, considering that vaccination coverage varies across professional groups: physicians (77.3\%), technical personnel (68\%), nurses (60.4\%), administrative/office personnel (15.4\%), cleaning staff (4.5\%). Another correlation was also found, among vaccination coverage and education level $(\mathrm{p}<0.001)$, (Table 6). Professionals of primary/secondary education had significantly lower vaccination coverage percentages than those of higher/university level education.

Another correlation was found among vaccination coverage and job position; professionals working in Special Care Units had the highest coverage percentage $(78.8 \%)$, followed by professionals of the Internal Medicine Depts. (75.0\%), professionals of the Surgical Depts. (62.7\%), and professionals working in the Laboratories (56\%). No correlation was detected among gender and years of employment.

Similar correlations among vaccination coverage and demographics were also detected by other authors [11], while others did not find such correlations $[7,19]$.

As far as professional exposure is concerned, $63.6 \%$ of those who suffered an accidental exposure reported a needlestick injury, lower than what Fiona Braka, Miriam Nanyunja, et al. found in a highly endemic country for Hepatitis B (77\%) [20], yet significantly higher compared to other studies reporting an average of 30\% [21-23].

We found encouraging the fact that only $0.3 \%$ of our participants were $\mathrm{HCV}$ positive, given that no vaccine against Hepatitis $\mathrm{C}$ is currently available, and the only prevention for HCWs is precaution during medical/nursing care.

Finally, a booster Diphtheria-Tetanus dose was not accepted by 
Citation: Saridi M, Toska A, Souliotis K, Orfanos N Sietou M, et al. (2011) Vaccination Coverage among Health Care Workers in A Greek Hospital. J Vaccines Vaccin 2:123. doi:10.4172/2157-7560.1000123

Page 6 of 8

\begin{tabular}{|l|l|l|}
\hline & N & $\%$ \\
\hline Hepatitis B Vaccination & & \\
\hline No & 8 & 36.4 \\
\hline Yes & 14 & 63.6 \\
\hline Number of Doses 1 & 0 & $0,0 \%$ \\
\hline 2 & 5 & 35.7 \\
\hline 3 & 9 & 64.3 \\
\hline Result & & \\
\hline Negative & 9 & 40.9 \\
\hline Positive & 13 & 59.1 \\
\hline HBsAg & & \\
\hline Negative & 22 & 100.0 \\
\hline Positive & 0 & 0.0 \\
\hline Anti-HBc & & \\
\hline Negative & 20 & 90.9 \\
\hline Positive & 2 & 9.1 \\
\hline Anti-HCV & & \\
\hline Negative & 22 & 100.0 \\
\hline Positive & 0 & 0.0 \\
\hline Anti Tetanus vac. & & \\
\hline Negative & 19 & 86.4 \\
\hline Positive & 3 & 13.6 \\
\hline & & \\
\hline
\end{tabular}

Table 9: Vaccination Status of Accidentally Injured HCW's.

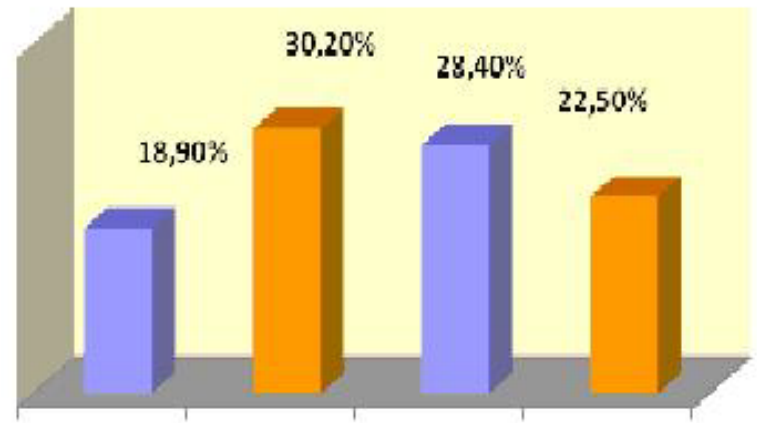

PIimtry Ed. Secondary Ed. Higher Ed. University Ed.

Figure 1: Education Level of Vaccines.

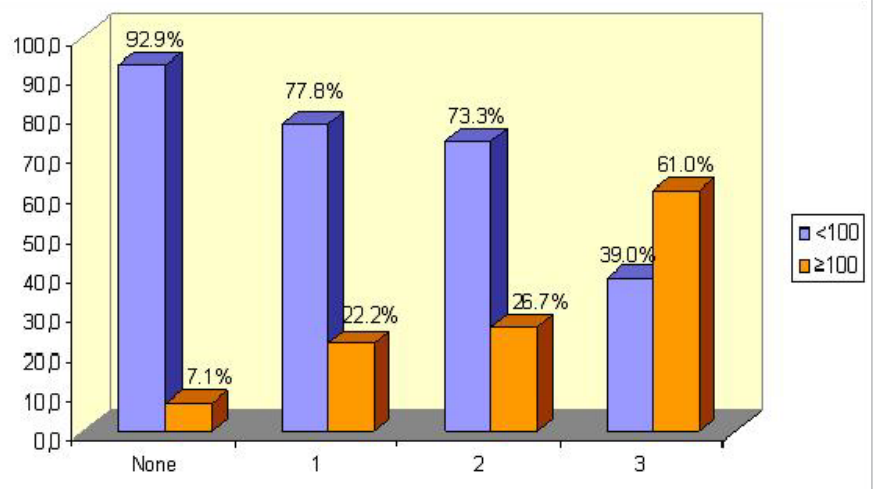

Figure 2: Antibody Level according to Number of Doses.

most of our participants (15.4\%). In many cases, the vaccination history was not clear (unregistered doses, loss of vaccine booklet, etc.), hence it remained unclear if any booster doses had been administered and when. The researchers had an easier task with the male population of

the sample, since all vaccines administered during their military service were registered in the Army records.

According to the international literature, HCW coverage against diphtheria and tetanus is poor. Only one Brazilian study [24] supplied data on HCW coverage, without further notice regarding booster DT doses.

According to the (Greek) National Immunization Program, most adults should be covered against diphtheria and tetanus, provided that they receive booster doses every 10 years -something that seems rather unrealistic. Although health professionals are not taken as a high risk group for tetanus, common injuries during work could make them susceptible to tetanus as well.

During our study, it became clear that most health professionals failed to remember if and when they had been administered a DT booster dose.

The new guidelines suggest that a booster DT dose should be administered without taking into account when/if a previous booster was administered, on condition that the initial three-dose series had been administered.

It was difficult to establish each professional's immunization history, especially of the older ones, due to loss of their personal vaccination records, and deficient registration of doses administered.

Other studies [25-27] suggest that there is a variance between the incidence of Tuberculosis among HCWs vs. the incidence in the general population; this finding could indicate a high probability of hospital-induced TB infections.

As far as our study is concerned, only a small percentage of HCWs (27.5\%) granted consent for a Mantoux Skin Test to be performed. The test was negative for $72 \%$ of them, and $28 \%$ were found to be Mantoux positive. Other studies on HCWs have found significantly higher Mantoux-positive results (about $60 \%$ of the sample), but since our sample was small, our result remains inconclusive. Nevertheless, a further X-ray and Laboratory examination showed no trace of latent TB infection [28-31].

Professional exposure to blood/body fluids was reported by 22 individuals (6.5\%). Although $63 \%$ of those who suffered an injury were fully covered against Hepatitis B, $23 \%(n=5)$ wanted to receive immunoglobulin, despite the fact that their antibody levels were $>1000$ $\mathrm{mIU} / \mathrm{mL}$, perhaps because of poor information or because they were under stress or fear.

In another study from Greece, most nurses (86.8\%) [15] consider

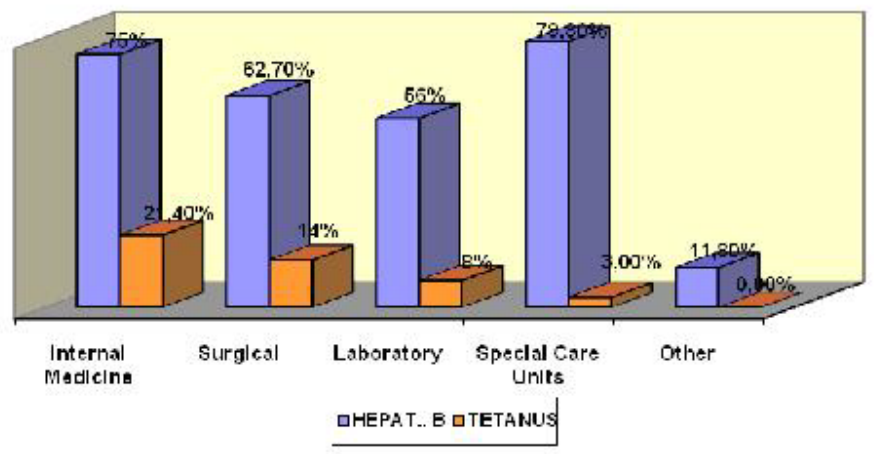

Figure 3: Vaccination against Hep. B and Tetanus According to Hospital Depts. 
immunoglobulin to be an important weapon in case of exposure to (potentially infectious) body fluids; similarly, during our study several HCWs asked to receive immunoglobulin, although they knew that they were fully covered against Hepatitis B.

The present study showed a correlation among exposure, gender, and years of employment. Male professionals with many years of employment have the higher exposure percentage. We also found that needlestick injuries were more common in unvaccinated professionals.

Other studies point also toward a correlation among exposure and gender [23], but other authors [13] have not detected any correlation among vaccination status and types of professional exposure.

After having completed our study, we realized that maintaining a high immunization level is a difficult task which requires the collaboration of a wide variety of health care providers. On one hand, Infection Control staff should thoroughly monitor vaccination programs of individual health care providers especially those who has significantly lower vaccination coverage percentages. On the other hand, hospital administrations should be encouraged to apply a compact immunization policy for each and every professional working there and governments should address particular interventions to improve vaccine uptake like incentives, reminder systems and flexible clinic times.

\section{Conclusions}

The present study not only recorded the immunological profile of health professionals working in a medium-sized hospital, but launched a systematic vaccination and screening program regarding Hepatitis B, Hepatitis C, Tuberculosis, and Tetanus -infections that present a higher risk of professional exposure. Our results should be compared to those of other Greek hospitals.

It is a known fact that HCWs vaccination in Greece is a matter of personal will. On the other hand, compliance depends largely on each one's education and information level. The CDC and the Greek Disease Control and Prevention Center guidelines are given as mere recommendations, contrary to what happens in other countries, like Great Britain or the United States, where health professionals' vaccination is obligatory.

In Greece, the mandatory pre-employment health examination for Health Care Workers includes for the most part a chest X-ray. Only cleaning staff and those who handle food materials have to be tested for Hepatitis, or other conditions like chronic salmonellosis. No kind of vaccination is mandatory before someone's employment. All vaccination-related guidelines are given as recommendations, thus creating a vicious cycle for HCWs who remain confused about what vaccines are suitable for them.

Also, most health professionals seem to have limited knowledge about passive immunization in case of professional accidents (e.g. needlestick injuries), for instance they usually ignore when it should be provided and what could be expected from its use.

On the other hand, a few vaccines were included in the new National Vaccination Program (e.g. Hepatitis B vaccine was added in 1998), which will eventually boost the vaccination coverage percentage as new health professionals will enter hospitals and other health care institutions.

It is widely known that continuous information and training can keep HCWs updated on matters of passive/active immunization and also on personal protection measures, measures that eventually guarantee the protection of their patients and families.

It should also be emphasized that each professional should keep their vaccination record updated. Training programs are important, but in order for the results to be permanent, those programs should be intensive and continuous.

\section{Restrictions}

The carrying out of our study presented a few restrictions. An important restriction for conducting this two-year-long study was the Infection Control Nurse's limited time and multiple job tasks.

Also, rotating shift work made it difficult for the Authors to contact all health professionals when they were available; it also made it difficult to record all professional accidents exactly at the time they occurred.

Another restriction for the Authors was the fact that many professionals did not consent to be vaccinated, because they were worried about the side-effects, or even about the confidentiality concerning their private information (although that was explicitly guaranteed by the Authors).

The Laboratory work-load and the respective financial cost were overcome due to the long duration of the program, as well as the expected advantages stemming from well-informed HCWs, immunologically able to deal with infection risks, common in hospital work.

\section{References}

1. CDC (1996) Hepatitis surveillance report No. 56. Atlanta: U.S. Department of Health and Human Services, Public Health Service, Centers for Disease Control and Prevention 56: 1-33.

2. CDC (1989) Guidelines for prevention of transmission of human immunodeficiency virus and hepatitis B virus to health-care and public-safety workers: a response to P. L. 100-607, The Health. Omnibus Programs Extension Act of 1988. Atlanta, GA.: U.S. Department of Health and Human Services, Public Health Service, Centers for Disease Control: 1-45.

3. Hepatitis B Virus Occupational Exposure (2006) A Fact sheet for health care and emergency service providers, BC Hepatitis Services a Division of the BC Centre for Disease Control.

4. Grob PJ (1999) Report on Working Group 2: Austria, Belgium, Bulgaria Germany, Greece, Hungary, Malta, Russia, Switzerland, Turkey and Uzbekistan. Vaccine 17: 2472.

5. Mc Ewen M, Farren E (2005) Actions and beliefs related to hepatitis B and influenza immunization among registered nurses in Texas. Publ Health Nurs 22: $230-239$

6. King WD, Woolhandler SJ, Brown AF, Jiang L, Kevorkian K, et al. (2006) Influenza Vaccination and Health Care Workers in the United States. J Gen Intern Med 21:181-184.

7. Manso VF, Castro KF , Sirley Matos, Junqueira AL, Souza SB, et al. (2003) Compliance with hepatitis $B$ virus vaccination and risk of occupational exposure to blood and other body fluids in intensive care department personnel in Brazil. Am J Infect Control 31: 431-434.

8. Brotherton JM, Bartlett MJ, Muscatello DJ, Campbell-Lloyd S, Stewart K, et al. (2003) Do we practice what we preach? Healthcare worker screening and vaccination. Am J Infect Control 31: 144-150.

9. Vandersmissen G, Moens G, Vranckx R, de Schryver A, Jacques P (2000) Occupational risk of infection by varicella zoster virus in Belgian healthcare workers: a seroprevalence study. Occup Environ Med 57: 621-626.

10. Mc Phillips H, Marcuse EK (2001) Vaccine safety. Current problems in Pediatrics, 31: 95-121.

11. Dannetun E, Tegnell A, Torner A, Giesecke J (2006) Coverage of Hepatitis B vaccination in Swedish health care workers. J Hosp Infect 63: 201-204.

12. Louther J, Feldman J, Rivera P, Villa N, DeHovitz J, et al. (1998) Hepatitis 
Citation: Saridi M, Toska A, Souliotis K, Orfanos N Sietou M, et al. (2011) Vaccination Coverage among Health Care Workers in A Greek Hospital. J Vaccines Vaccin 2:123. doi:10.4172/2157-7560.1000123

Page 8 of 8

B vaccination program at a New York City hospital: seroprevelance, seroconversion, and declination. Am J Infect Control 26: 423-427.

13. Spence MR, Dash GP. Hepatitis B (1990) perceptions, knowledge and vaccine acceptance among registered nurses in high- risk occupations in a university hospital. Infect Control Hosp Epidemiol 11: 129-133.

14. Fatusi AO, Fatusi OA, Esimai AO, Onayade AA, Ojo OS (2000) Acceptance of hepatitis $B$ vaccine by workers in a Nigerian teaching hospital. East Afr Med J 77: 608-612.

15. Noula M, lordanou P, Gessouli E, Evagelou E (2002) The Nurses awareness of the occupational risk regarding hepatitis $\mathrm{B}, \mathrm{ICU}$ and Nursing Web Journal 10: $1108-1114$

16. Noula M, Raftopoulos V, Gesouli E, Tsaprounis T, Deltsidou A. (2008) Greek nursing students' immunization coverage: data from central continental Greece, Nurs Health Sci 10: 169-174.

17. Geier DA, and Geier MR (2002) One year follow up of chronic arthritis following rubella and hepatitis $B$ vaccination based upon analysis of the VAERS database. Clin Exp Reumatol 20: 767-771.

18. Zielińiska-Jankiewicz K, Kozajda A, Szadkowska-Stańczyk I. (2005) Protection of hospital workers from risks of occupational exposure to biological agents. Med Pr. 56: 367-373.

19. Nakayama T, Aizawa C, Kuno-Sakai H (1999) A clinical analysis of gelatin allergy and determination of its causal relationship to the previous administration of gelatin containing acellular pertussis vaccine combined with diphtheria and tetanus toxoids. J Allergy Clin Immunol 103: 321-325.

20. Braka F, Nanyunja M, Makumbi I, Mbabazi W, Kasasa S, et al. (2006) Hepatitis $B$ infection among health workers in Uganda: Evidence of the need for health worker protection. Vaccine. 24: 6930-6937.

21. Gershon RR, Mitchell C, Sherman MF, Vlahov D, Lears MK, et al (2005). Hepatitis $B$ vaccination in correctional health care workers. Am J Infect Control. 33: $510-518$.

22. Suckling RM, Taegtmeyer M, Nguku PM, Al-Abri SS, Kibaru J, et al. (2006)
Susceptibility of healthcare workers in Kenya to hepatitis B: new strategies for facilitating vaccination uptake. J Hosp Infect. 64: 271-277

23. Syed F Shah SF, Abdulbari Bener, Saad Al-Kaabi, Abdul Latif AL. Khal, Soji Samson (2006) The epidemiology of needle stick injuries among health care workers in a newly developed country. Safety Science 44: 387-394.

24. Dos Santos AM, Ono E, Lobato RT, do Prado SI, Kopelman BI, et al (2008) Diphtheria, tetanus, and varicella immunity in health care workers in neonatal units, Am J Infect Control. 36: 142-147.

25. Joshi R, Reingold AL, Menzies D, Pai M (2006) Tuberculosis among healthcare workers in low- and middle-income countries: a systematic review. PLoS Med. 3: 494

26. Menzies D, Joshi R, Pai M (2007) Risk of tuberculosis infection and disease associated with work in health care settings. Int $\mathrm{J}$ Tuberc Lung Dis. 11: 593605.

27. Pai M, Gokhale K, Joshi R, Dogra S, Kalantri S, et al (2005) Mycobacterium tuberculosis infection in health care workers in rural India: comparison of a whole-blood interferon gamma assay with tuberculin skin testing. JAMA. 293: 2746-2755.

28. Roth VR, Garrett DO, Laserson KF, Starling CE, Kritski AL, et al (2005) A multicenter evaluation of tuberculin skin test positivity and conversion among health care workers in Brazilian hospitals. Int J Tuberculung Dis 9: 1335-1342.

29. Ozdemir D, Annakkaya AN, Tarhan G, Sencan I, Cesur S, et al (2007) Comparison of the tuberculin skin test and the quantiferon test for latent Mycobacterium tuberculosis infections in health care workers in Turkey. Jpn J Infect Dis. 60: 102-105.

30. Lopes LK, Teles SA, Souza AC, Rabahi MF, Tipple AF (2008) Tuberculosis risk among nursing professionals from Central Brazil. Am J Infect Control. 36 148-51.

31. Pearson ML, Jereb JA, Frieden TR, Crawford JT, Davis BJ, et al (1992) Nosocomial transmission of multidrug-resistant Mycobacterium tuberculosis. A risk to patients and health care workers. Ann Intern Med 117: 191-6. 